\title{
Werner W. Franke: Congratulations on the occasion of his seventy fifth birthday
}

\author{
Klaus Unsicker
}

Published online: 29 January 2015

(C) Springer-Verlag Berlin Heidelberg 2015

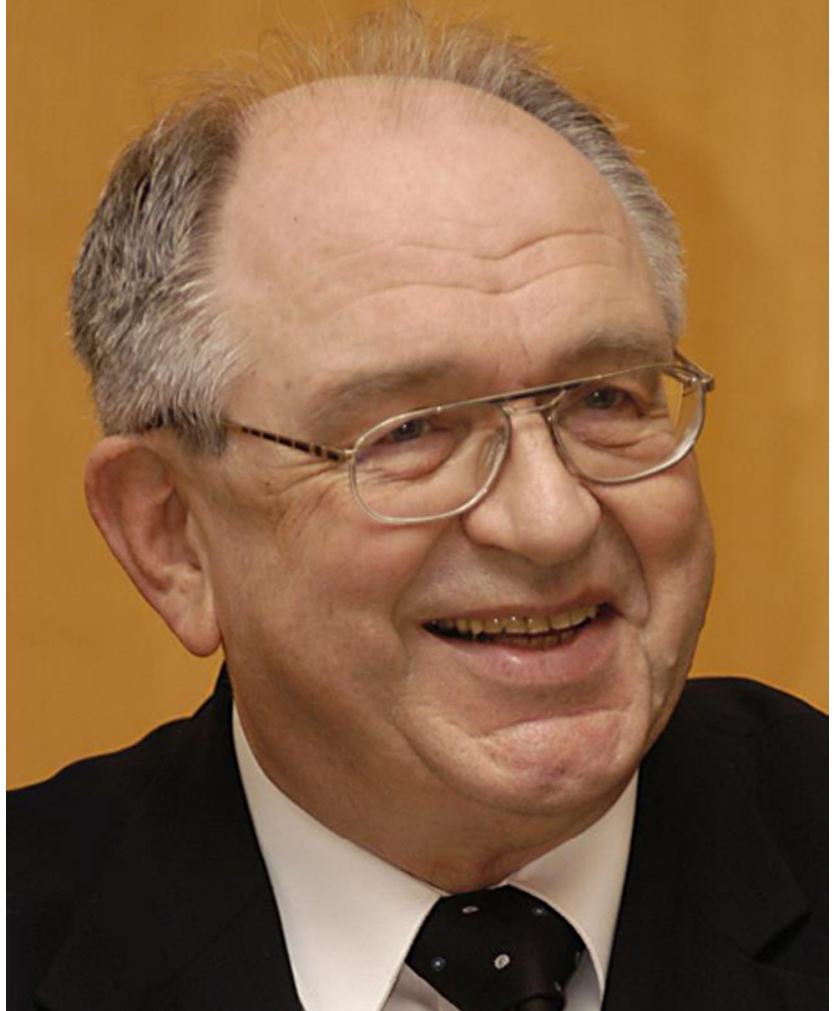

Meeting Werner Franke these days, you would certainly never guess that he celebrated his seventy fifth birthday on January 31, 2015. Highly dynamic, bursting with ideas, always giving the impression that he is permanently dealing with half a dozen different topics and pursuing a dozen different activities simultaneously, be it science or doping issues - he simply

\section{K. Unsicker $(\bowtie)$}

Institute of Anatomy and Cell Biology, Department of Molecular

Embryology, University of Freiburg, Albertstr. 17,

79104 Freiburg, Germany

e-mail: ku39@anat.uni-freiburg.de continues to be the person he has been all through his life: outspoken, not always a diplomat, the colleague with the sharp analytical understanding that we highly esteem, the valued member of our Editorial Board, the internationally acknowledged expert in so many different fields of cell biology, most notably the cytoskeleton, and current head of the Helmholtz Senior Group for Cell Biology at the German Cancer Research Center (DKFZ).

Werner Franke was born on January 31, 1940, in Paderborn, East Westphalia, a region with a reputation for generating more self-willed headstrong personalities than any other part of Germany. He studied Biology, Chemistry, and Physics at Heidelberg University, became Assistant and Associate Professor at the Department of Biology, University of Freiburg, and was appointed Professor at the Faculty of Biology and Head at the DKFZ Heidelberg at the young age of 33. There, for the next 40 years - and still continuing - he began to identify and characterize the fiber matrix and junctions of various cell types in relation to their states of differentiation and malignancy, making hallmark discoveries, for example, in the fields of keratins and vimentin, and performing "anti-dogmatic" research on diverse kinds of cell-cell adhering junctions usually excluded from textbooks, addressing tumor cell spreading, invasion, and metastasis, and transdifferentiation, to name just a few lines of his research. He has generated multitudes of antibodies, many of them being in global use for scientific and diagnostic purposes.

His research has brought Werner Franke international recognition, honours, and awards. For a decade, he was the Associated Editor of the Journal of Cell Biology (JCB) for Europe, acted as a JCB Board Member for 27 years, and served on the Editorial Board of many more prestigious journals. He acted as president, vice-president, and chairman of many learned societies, advisory boards, and grant-giving bodies, including the European Cell Biology Organization (ECBO), the International Federation of Cell Biology, the International Society of Differentiation, the German Society 
for Cell Biology, and the Conseil Scientifique of the Institut Curie, Paris. Among the prizes that he has received are the Meyenburg Prize for Cancer Research, the Ernst Jung Prize, the Anders Retzius (Karolinska), Feulgen, Tinsley R. Harrision, Carl Zeiss and Hans Bloemendahl Lectures, the Feldberg Prize, and the German Cancer Prize, not forgetting his election as "Professor of the Year" of the German Academic Association (Bonn). The ISI index shows that Werner Franke has published over 660 original articles; he is among the most cited German cell and molecular biologists (see Most Highly Cited Researchers Database, ISI, Category Molecular Biology and Genetics, 2001).

To the wider public, Werner Franke is known as a determined fighter against doping and a whistle-blower drawing attention to all sorts of drug abuse in competitive sport. Together with his wife, Brigitte Berendonk, he has uncovered government-sponsored doping in the former German Democratic Republic. Without showing any signs of tiring, he applies the spirit of sportsmanship - he was an athlete in his younger years - and continues arguing and fighting against doping at all levels, through the media, committees, and in court. Had he not been a professional satirist in his early years writing scripts for cabarets such as "Kom(m)ödchen" (Düsseldorf) and "Bügelbrett" (Heidelberg), we might wonder from what profound sources of his character he recruits the energy for continuing the battle.

The impossibility of comprehensively praising Werner Franke's achievements is evident, given the abundance of merits that he has accumulated over 75 years. However, from the CTR perspective, at least one more word needs to be said: it is wonderful to have Werner as a Section Editor for "Molecular/Cell Biology", to have him on the Editorial Board, and to benefit from his analytical strength and uncompromising advocacy for quality and honesty in science.

Werner - thank you! We wish you many more years to come, all filled with your energy and strength of purpose.

Ad multos annos!

Klaus Unsicker

and the members of the CTR Editorial Board 